IDEA - Studia nad strukturą i rozwojem pojęć filozoficznych $\mathrm{XXIX/2}$ Białystok 2017

\author{
Paul I. Ogugua \\ (Awka, Nigeria)
}

\title{
DIALOGUE AND INVOLVEMENT: \\ A BLUEPRINT FOR HUMAN, HUMANE AND HARMONIOUS RELATION BETWEEN AFRICAN AMERICANS AND AFRICANS
}

\section{Introduction}

A sceptre of revolution looms large, in short, it has engulfed the human race. It is a revolution against the good, the true and the beautiful. Another dark age is gradually but steadily setting in; and leaders of men with their skills and sharpened reflexes, scheme continuously, plotting and re-plotting, think that diplomacy will do. The fact is that they are in error, for through diplomacy they dig the grave for mankind deeper and the danger becomes more pronounced.

For many centuries the human race has known division into two classes: the privileged and the unprivileged; the exploiter and the exploited; the colonized and the colonizer, etc. There were and still are the haves and have-nots: capital and labour, in short, there is disunity everywhere, even the present globalization trend thickens this divide.

It has dawned on us that human relations need to be handled properly and with a plan or else we all will land crash and end in quaqrnire as the world will be plunged into the bloodiest war in history. We have to do this because the dawn of knowledge has come, and we have with the aid of hind sight and foresight imagined how deadly it will be. Africa is the cradle of civilization and mankind, and it is our onus to hold high this feat of our ancestors; and because we love ourselves and the other(s). 
The problem is that human relations have not been based on nature's law of balance, which stresses on natural methods of interchange which inevitably generates continuity in love.

A pivotal question raises its head at this point. How would balance be restored to the troubled waters in human affairs? This could be done by beginning to turn the tide in human affairs, as it is done, normalcy will return as the tide will be forced to reverse its flow. How do we turn this tide in human affairs? It is the position of this paper to show that we could use dialogue and involvement to restore this tide which has gone off tangent, not only with mankind but more so and faster between the African Americans and Africans as both groups so to say have a lot in common to facilitate the realization of this noble objective (harmonious relation and human fulfillment).

This paper which is geared towards the wholeness of the human person, the meaningfulness and integrity of interpersonal relationships will definitely sound bizarre, other worldly and introduce a sort of uneasiness, which might open the door to commotion but eventually it will reveal the beacon of peace and progress and light the candle that will shade light and show the way to greatness through dialogue, participation and connectedness (relatedness). This paper will apply a trilogy of logic(s): the logic of revelation (of course of the given): the logic of analysis: and the logic of interpretation, specifically grounded on a metaphysics of personality which holds that personality is the key to life and reality, the master key for unlocking the goodies in every human society.

This paper which treats person as sacred, an infinity of intrinsic value', is then a philosophy of combat action; an intellectual excursion, a religious refocusing, redirection repositioning and even reconversion to ensure that values, both human and spiritual, are respected. It will take the following format: Now that the introduction is over, I will look at the common ground from where to take off .Next, I will examine the concept of dialogue and the principles of dialogue. Be it as it may, this paper does not pretend to have clinched the discourse on this topic, as it neither pretends to pass a final judgement nor to have taken a seat in final truth. 


\section{African Americans and Africans: any common grounds?}

It was Bierstedt who once said: Influence attaches to an idea a doctrine or a creed and has locus in the ideological sphere... ideas are influential, they can change the course of history.

Many a scholar have said ideas rule the world. I do not disagree, but at a more empirical level interests (which are coloured, femented and dressed or cherished ideas) rule the world. An African remains an African everywhere and at every time. Do you know that to be African is to be natural or close to nature? We have an idea being canvassed - that Africans need to know each other. An interest is equally being canvassed - that Africans need be interested in each other and map out ways to realize themselves irrespective of the fact that tongues, languages and clime may differ.

We ask at this juncture, what are the elements of commonality between African Americans and Africans? The word' African' has many referents such as: geographic, racial, ethnic, epistemic, ideological, ontological, ancient, medieval, modem, contemporary, etc. in our context, we have to see this term as a noun and an adjective. Which ever way we see it, the term 'African' pre-fixed to Americans qualifies the term Americans: that qualification is necessary or else it looses its meaning. We could talk of a general ground of commonness or relatedness between African Americans and Africans, and that will anchor on our humanity or personality, and a specific ground of relatedness if we think of African personality on account of which one can rightly talk of African understanding, of course grounded on African ontology.

\subsection{The principle of humanity:}

Philosophically speaking, this principle of humanity is expressed in a theory of idealism 'Called personalism. Apart from personalists, more precisely personalist philosophers, some others have testified to the value, worth and dignity of man.

Theologically, the Greek word 'hypostasis' meaning 'standing under', is related to 'ousia' Greek word meaning substance. These Greek words are related to 'persona' a latin word meaning mask or an actor (or actress). No doubt, the Greek attached great value and dignity to man., Boethius defined a person thus: 
Persona est nature rationabilis individua substantia A person is an individual substance of rational nature.

It is from 'persona' that the term personalism sprang up. One, irrespective of whatever happens, cannot cease to be a person. Sahakin et al (1965:495) underscored this point thus: Personality is something given, we do not create it, nor do we know how it is created.

That shows that persons are essentially related to one another; the idea which unites them with the unifying spirit of the world.

Protagoras, in Stumpf (1971:34) expressed: Man is the measure of all things, of things that are, that they are, of things that are not, that they are not.

Has he not made man the determiner of nature and events? What kind of honour? Man brought the world out of metaphysical comatose, by the use of language; and is the meaning-giving creature in the whole wide world. The Psalmist marveled at the creature - man and queried: What is man that you should keep him in mind and care for him... yet you have made him little less than a god with glory and honour you crowned him ...

Shakespeare in Hodek (1978:907) joined the psalmist and acclaimed: "What a piece of work is man; how noble in reason; how infinite in faculties; in form and moving". Aquinas lost in speculation remarked: "The person is the most noble and most perfect being in all of nature".

For Jean Reston, a French biologist as cited in Koop (]976:7) There is no life so degraded, debased, deteriorated or impoverished that it does not desire respect and is not worth defending with zeal and conviction.

It boils down to Soyinka's (1975:96) statement that: Human life has meaning only to that degree and as long as it is lived in the service of humanity. For me humanity is infinite.

These kinds of conceptions view points are represented by personalism, represented ably by Immanuel Mournier, Pope John Paul II, etc. Personalism [or Edwards (1968:107) is a philosophical perspective or system for which person is the ontological ultimate and [or which personality is thus the fundamental explanatory principle.

It is a system of thought according primacy to the human person in the entire scheme of things; that means man is the sole metaphysical reality, and as such has ultimate intrinsic value. In the words of Haring (1968:2) Personalism 
is man's protest against being treated as a cog in a wheel or an object to be exploited.

We can see from the foregoing that persons are essentially related to each other. Our survival rests therefore on the principle of dependency and reciprocity.

\subsection{African personality}

A metaphysics is at the bottom of every understanding of reality. David Hume, an arch empiricist, who doubted even the presence of the self or self identity consented to this thesis. The western metaphysics unlike African metaphysics is not person- centred or else why did Haring (1968: ) see personalism as: A spontaneous and often explosive reaction against a manner of thinking that is thing - oriented: against a way of planning and managing that manipulates man solely as an object.

Ogugua (2004:8) pointed out: The African can only be identified and fully defined totally and understood truly through ontology for he is a being-in-theAfrican-world. He is one who wishes to live desirously with this consciousness. ... He is not just a being, he is conscious of being a 'being-with. It is impossible to understand ourselves without African Ontology; this grounded the understanding of our ancestors. Our ontology gives us a common soul. Why did Cesaire (1972:76) assert that: "Our negro heritage was worthy of respect: that its values were values that could still make an important contribution to the world".

To really understand ourselves, we need to go back to our world view and the philosophy behind our thought and action. Ogugua (2004:9) writes: For the African, there is interaction and interconnections between things, little wonder, they conceived being as 'force'.

This force is not a quality of being. According to Onyewuenyi (1982:153). "the concept of force is inseperable from the definition of being". The idea of connectedness and relatedness is stressed among forces. Tempels (1959:58) rightly puts it thus: The world of forces is held like a spider's web of which no single thread can be caused to vibrate without shaking the whole net-work.

In the very words of Ogugua (2004:10) This idea of unity, togetherness and oneness in African understanding of existence which is existence-inrelation summarizes and sums up the African conception of reality. 
The African is a being-with, manifesting in different facets of his life. Do you wonder then why Africans are more outgoing than some other races? The African is not only a being-with-the-other, he is equally a being-for-the-other. His being-with is in the sense of becoming; not in the sense of intimacy. By implication, anyone could have this integrated African personality, just as an African by birth can loose touch with this personality, though he could regain it by living an authentic African way.

Now let us examine the concept of dialogue and the principles of dialogue.

\section{Dialogue Conceptualizing this Word Dialogue}

\subsection{Conceptuaslization of the Concept of Dialogue}

The concept comes from two Greek words 'dia; meaning between and 'legan' meaning 'to talk'. It then means talking together. For Oxford MiniReference Dictionary it means talk between people's.

Ogugua (2001: 15) stressed: The fact is that dialogue is more than a tetea-tete, any polite chat. It is even more than discussion. Most often when people speak with each other, no dialogue ensues.

He continued: In an age like ours where words are inflated, dialogue rarely takes place. Dialogue is complex, takes place when people come together in order to ensure human relations by attempting to overcome areas of prejudices ... in the bid at (sic) arrive at the truth and better the relationship.

In the words of Bishop Taylor dialogue means a: Sustained conversation between parties who are not saying the same thing and who recognize and respect the differences, the contradictions and the mutual exclusions between various ways of thinking.

In a broad sense, according to Chukwudozie (1979:7), it means a 'form of meeting and communication between individuals in a spirit of sincerity, respect for persons, and mutual trust'.

Dialogue implicitly involves the idea of accommodation and tolerance, which suggests openness to reality and the truth. Dialogue becomes then an encounter for openness with the other in the bid to know development peace and harmony. Three planes are associated with dialogue: the plane of human rela- 
tions, the plane of truth and the plane of action: representing the human ontological and practical dimensions of existence.

Dialogue for Ogugua (2001:16) involves a kind of movement, of rapprochement and deeper understanding. This is because underneath it is the idea of human person, human life, value and dignity. Dialogue is not defensive, not a defense of one's position, rather an encounter to discover the position of the other and study it in a spirit of love and truth.

\subsection{Principles of Dialogue}

Among the principles of dialogues include: openness, personal contact, cooperation and frankness of position or viewpoint.

\section{Openness:}

In order to have an encounter that is human-and on the place of search for the truth, all those involved in dialogue need be open minded and consistent in their openness. Openness is a risk, for it involves exposure. But this exposure worths it if people must sustain the society which is based on trust. Ogugua (2001 :24) opines, if dialogue must exist we need:

The exhibition of a mind at its fullest powers, a sensibility engaged, nurtured and enriched by exposure to reality, an experienced mind which must be ever ready to shift grounds and change as the case may be if it comes in contact with new aspects of truth of lessons of great insights, of things he might not have thought about.

There is a kind of relationship between openness and honesty; openness and sincerity.

\section{Personal Contact:}

Dialogue involves contact, an encounter with the other: or group with another. It elicits a kind of respect for the other, and even acceptance of the other. If dialogue really exists, and not a make believe type, superficial encounters will be automatically transformed into human and realistic encounters. At this stage, competition dissolves, comparisrn goes and cooperation and search for insights take over the platform putting to rest the atmosphere of suspicion. 
It is only at this level that the unsuspected depth of our personality could be reached and God encountered.

\section{Cooperation:}

Dialogue is not meant to only speculate; the ideas, insights discovered need to be put to work in order to enrich the selves and the society. This is the plane of action. The subject of dialogue is man, likewise the object of dialogue is (man) human aspirations Chukwulozie (1979) writes:

Dialogue should be less concerned with the problems of the past which worried our predecessors, but of which we must be aware in order to understand their influence on both sides in the dialogue, and more with the problems of today which involves element different from those of former days.

In short, an 'I - thou' and not 'I - it' relationship postulated by Martin Buber is advocated.

\section{Frankness of viewpoint:}

We need honesty and sincerity and even love and regard for the other in order to postulate frankly our opinions and positions, and real studies in order to get into the shoes of the other. Man is a cultural animal, so to understand him we need to understand the culture. And language he uses to express this culture; for language and thought have a way of shaping reality. It is by getting at the mentality of the other that we open the path to real and effective mutual understanding. Ogugua 92001:25) attested: Expression of one's position in a frank manner and listening to the other's position in order to gain insight is a hallmark of a mature mind.

\subsection{Hinderances to Dialogue}

A distinction needs to be made between having a disposition to dialogue with someone and really being involved in dialogue with the person. Not to engage in dialogue and communication is a plague for we get closed up, and we loose a part of our being. Or else why is man furnished with the faculty of concept formation and gift of speech? We cannot realistically engage in communication with great number of people or else we ruin communication and fill our 
life with fads and superficialities. We can rightly infer then that communication is not obstacle free.

There could be misunderstanding of concepts, ideas. options, intentions, and even values pursued, even in discussions with family members and friends.

Man is most of the time selfish and rarely altruistic. In short, the self is central in what human beings do. Men think most of the times of themselves first. Or else why did Sartre see the other as hell, hindering one's freedom? Or why is it that men tend by their policies and actions to deny the humanity of the other? Most times, it is difficult to see people reaching a consensus easily or get at mutual concession. A pivotal question raises its head (here arrd now) 'hic et nunc': is common sense really common? Is man still a rational animal? Or else why does interest override reason? Why the screen being erected between man and man?

Ogugua ( 00\}: 4) poignantly stressed:

We are all human beings, but deep down in us there is an irreducible opacity about the way we see life and do things that tend to cling to the belief that we are different from the other and hence generate indifference towards the other.

Some people tend to pretend to be in communication but are not. A few might choose to be incommunicative. The fact remains that he who is afraid of change, of changing his opinions and

positions with the appearance and emergence of new facts and insights cannot really engage in communication. That person is afraid of risk, the truth and cannot live realistically, that person is immature.

\subsection{Rules of Dialogue}

Some rules should be obeyed and seen as laws if the dividend associated with dialogue should be earned. These include:

a Recognition of the ontological equality of all persons. We are all equal before God. And equal before the law or else why is the law said to be no respecter of persons. This implies that accidents associated to any person or group need to be downplayed, such as wealth, age, position, culture, tradition, tribe, religion, social class etc. These should not carry any weight in the issue discussed. 
b. The parties involved in a dialogue need exercise patience or else tolerance cannot be ev- ident. Tolerance and patience grounded on respect for the human person make it possible for one to listen to what the other says.

Most of the time, most people listen very poorly and this could be due to a lot of things: lack of concentration, listening too hard; lack of interest, inordinate and ill desire, or desire to conclude immediately in a hurry, focusing on the appearance of the talker, being overwhelmed by the method of delivery of one's speech or position, etc. We could improve listening so as to get at understanding by taking listening seriously, learning the art of listening, cultivating the desire and attitude of listening, learning to resist distractions, having focused listening, suspending judgement refusing to be distracted by appearance, fad or delivery, etc.

c. Effort must be made to place oneself in the other's position. Without entering into the mentality of the other there will be no common ground for any meaningful and fruitful dialogue. To do this suggests accepting the other as he is and not striving hard to make him conform to our idea of him.

d. We must make room for differences of opinions, beliefs, etc. We must respect the other and his viewpoint, most often his viewpoint is coloured by his religion and culture, and these are one's life. This idea is given support by Plattel (1965:2), he says the home of contemporary man: does not lie primarily in a localized milieu but in his fellow-man, man becomes a person only when he feels that his fellow-man affirms him as such .... indicated as his co-existence.

e. There is need for truthfulness, sincerity, love for the truth, honesty. transparency in actions. There is need for the parties in a dialogue to abide by the resolutions of the bodies organizing the dialogue. Commitment is the watchword. This should be in view of redeeming relationships.

\section{Involvement: What is it?}

Involvement does not mean being disposed. It does not mean being available, it rather means something more. It connotes being soaked in, really engaging in and not being passive.

It does suggest an idea of activity, joining with love, full of life. Involvement presents to the fore what somebody is and represents, for in being involved one is no longer hidden, he is in the open; he risks exposure and being 
judged. Haring (1968:27) writes: Human activity, to be sure takes its significance from its relationship to man. Just as it proceeds from man, so it is ordered toward man.

Being involved suggests an idea of participation. The concepts of involvement, participation., freedom, conscience and responsibility are interwoven and related. Responsibility strictly speaking cannot exclude accountability. Involvement as a process permeates the entire life of the African; for the Africans are known for communalism, their communitarian, and communion kind of life. They believe that an 'I' is one of the lines of the 'we'; and that to exist authentically means existing in the community, participating in the way of life of the community, in short, being involved.

Mbiti (1969:2) holds: To be human is to belong to the whole community, and to do so involves participating in the beliefs, ceremonies, rituals and festivals of that community.

This is grounded on the principle of relatedness. Tempels (I969:60) emphasizes for the Africans (who hold that being is force and vice versa) that: The world of forces is held like spider's web of which no single thread can be caused to vibrate without shaking the whole net-work.

Participation will involve development of a kind of partnership structure, for the protection of interests of all the interests involved. Every rational person should see that he engages in it in order to enrich self and social life. Haring (1981 :369) attests to this thus: Creative liberty, creative covenant fidelity and shared responsibility are fundamental values not only for individual selfrealization but also for all dimensions of social life.

Involvement is a kind of moral calculus of relation (and even power), it will concern mutual responsibilities of inequality. In short, it entails total responsibility of an individual or/ and group to the other or/and group(s). It can be seen as the moral foundation for any kind of relationship. Do you know that individual rights and active participation or involvement are related, or interdependent to be more precise? Active participation or involvement cannot spring up in any area or society where individual rights are trampled on and left not respected.

Real participation or involvement must be at the plane/level of humanity.

Octogesima adveniens advocates:

This legitimate aspiration (that is the sense of sharing of responsibility (mine) becomes more evident as the cultural level rises and the sense of freedom develops, 
and as man becomes more aware of how, in a world facing an uncertain future, the choices of today already condition the life of tomorrow.

Involvement entails obedience, but at times resistance and civil disobedience are the best things we could do to help the society, more precisely the State or injustice will lead to disaster. Man is a hoper, he expects tomorrow to be better, this cannot be save man involves himself not only in planning and developing policies but in working out these policies. Man is a 'No' and 'Yes' creature, 'no' to things that degrade him and 'yes' to things that enrich and develop him.

Human hope sunk in involvement should be creative and militant as Christian hope. Involvement could be said to be a process of conscious - raising geared towards revolution" for being" according to Lagos (1977). For Haring (1981 :375) Human hopes, and particularly the Christian hope based on divine promises and on the gospel of conversion, cannot accept an unjust and dehumanizing social, economic and political status quo.

Involvement calls for a change in traditional way of human relationships. Involvement connotes equality, as man is a social animal. Russell (1954: 17) writes: We must therefore admit two distinct elements in human excellence, one social, the other solitary.

Our acceptance of involvement as a cardinal doctrine to get at harmony in human relationship shows we avoided solitariness. Solitariness in a social and gregarious animal is queer and a sort of punishment.

Indeed, my vision of involvement, with whole and total commitment to social love and justice on the levels of being. humanity, human relations. truth, action (all levels), means more than any form of radical change which would come about through the power of the barrels of gun or any violent means. Haring (1968: 7) supports us thus: ... all that men do to obtain greater social justice, wider brotherhood, a more human ordering of social relationships has greater worth than technical advances. 


\section{Dialogue and Involvement: a Blueprint for Harmonious Relations Between African Americans and Africans.}

In life man is thrown into the world, not abandoned, rather he discovers himself in the world of persons, things, spirits and forces. To remain in harmony with and in himself, he must learn to coordinate perfect relationship with these. We know from experience and studies that he has vertical and horizontal levels of relationship. On the vertical level, he relates with God, and on the horizontal level he relates with/to men, representing spheres of religion and morality respectively.

Experience has taught us and religion too that man is made in the image of God. Underlying his personality is a spark of God, (vita elan), the thread of life, a thread of being. To really enter into dialogue with man we must first and foremost listen to God within us. Without it we cannot listen to the other.

So, one of the primary rules of dialogue is listening to God, this would aid us accept ourselves with our abilities and limitations, and using to the fullest every opportunity that raises its head. This entails too, giving first place to persons and communities so as to witness enriching relationships.

Our abstract knowledge can no longer usurp the position of love for truth. We will all the more be better disposed to search for the truth and not certainties. If we get stuck up in our search for certainties, we will become technical, scientific, caged and loose the touch of humanity. Human relations must not do with precision, it is not a measurable, and quantifiable science.

The emphasis here is on the establishment of a planetary African - African American society, of course on a planetary social justice and spirituality. Today we can no longer speak meaningfully of Africanity, African blood, son of the soil, Africa being the cradle of mankind and civilization without nursing, cultivating a burning zeal, enthusiasm for building an authentic and solid African: - African - American community, where rights of Africans everywhere in the world are acknowledged, respected and common good of Africans sought.

This paper envisions a new African wide, worldwide African consciousness that Africans both in Africa and Diaspora are one, and have no future unless we develop even fanatically and intoxicated' a new attitude and put in place new structures in every facet of life in order to show and register this solidarity and oneness. We can ask at this point, is dialogue really necessary? 


\subsection{The Necessity of dialogue and involvement}

Dialogue gears towards the establishment of relationship. We can only remain ourselves by moving out of ourselves (cocoons/shells) without this we cannot be fulfilled.

Mounier cited by Ifemeje, Charles (1983:13) writes: 'We must find our way out of our inwardness, in order to sustain that inwardness'. This is because man is not a solitary animal but a social one, and is truly human when he relates with the other(s). Man is a being - with - the - other.

This relationship is grounded on morality, more precisely on the principles of universal moral law, the first, being "good, is to be done and evil avoided".

Mounier in Edwards (1968:411) holds that: 'Man's chief task, is not to master nature but, increasingly to bring about communication leading to universal understanding'.

Dialogue invariably could lead to co-existence, that is respect for the other and affirmation of the other as a person with worth, value and dignity.

In communication, revelation of the self is made, the self is made manifest, it is in the open, and openness strikes the cord of invitation to human relation and fulfillment. Is it then surprising to hear Jaspers (1970:54) state: An avoidance of true communication is tantamount to a relinquishment of any selfbeing, if I withdraw from it, I am betraying not only the other "but myself .And Freidman (1964:204) too emphasized: In communication, I am revealed to myself together with the other, for in becoming manifest, I am losing myself (as empirical existence) in order to find myself (as potential Existenz).

Implicitly, not to communicate, let alone not to be in dialogue, or more so, not to be involved, is to extricate the deepest root of one's being. Freidman (1964:204) added:

... this communication is not blind love, indifferent to its object, but a contending love which is clear-sighted. It challenges, complicates, demands and draws the other potential Existenz out of his potentiality.

It is a truism that no one can be on his own all alone; no one is self sufficient We depend on the other through life, to do this meaningfully and realistically we must engage in communication. An isolated human being is strange, not only in reality but even as a concept. Higgins (1949:359) testifies to this 
thus: " men do not live isolated lives but have ever acted as members of some group".

\subsection{Dialogue: a step to cooperation}

Dialogue could lead to cooperation if it is neither captious nor condemnatory. It should be a sincere encounter, a real encounter and an open one.

We need dialogue in order to overcome the grudges we have for each other, and the dangerous defensive mechanisms we have already put in place to checkmate the other. Each of us has the power to destroy and undo the other, if it is not by brawl, it could be through evil machination. No one or group is entirely bereft of power. (There could be power in deceit) A reference to Eve and the snake in Genesis account (of creation) will show.

Knowledge of this situation should compel us all the more to enter into really constructive dialogue in order to keep our hopes and African hope alive. The "purpose of dialogue is mutual knowledge, acceptance and understanding; and even love, for John Donne said, no man is an island, he is a piece of the main. Dialogue is a virtue encapsulating many other basic human virtues; in this light it is spiritual. For Haring (1979:365)

By "dialogue" we understand an encounter characterized by mutual listening and readiness to respond in full freedom and total sincerity, an exchange of communications in which the participants act as partners.

Reading creatively, this passage will reveal that dialogue has something to do with discernment. It then means that we must not be too officious, regimented, scientific in our relationship. We need not anchor rigidly on certainties, objective criteria, or making hair splitting or detailed distinctions, for human relations is not mathematics or science, it is wider than these, as life is wider than logic.

Dialogue should inject in us loving respect for the other, and unconditional acceptance of the other as a person(s) in the African community of persons. With the situation as said, it becomes easier for us to see and recognize common grounds between us, seek out these grounds if they are not too open, and establish factor(s) which unite us before even we get at the problems urging to be 
addressed. Between Africans and African-Americans, humanism, Africanity, humiliation, marginalization, etc tend to unite us.

We need a kind of humility to get into real dialogue, more especially on the part of Africans in diaspora; for partial identification cannot yield any meaningful dividend. There is need for full identity, they must identify with Africans, show themselves fully in their identity as Africans and believers in African cause. Of course, they need to realize that they have no root outside Africa; they are not Americans, rather they are African representatives in America. Only African-Americans, who are historical beings, mature and intelligent can with all their being, have a deep grasp of what we postulate in this paper should be able to enter into a creative, worthwhile and meaningful dialogue with Africans at home. Only this hope, this faith, this ambition, this desire can bring about a synthesis of the roots and depths of African cultural existence and the breadth of African history. Only dialogue can bring about the long solicited, thoughtout and hoped for cooperation. Real dialogue cannot remain at the theoretical level for long, it is action- packed, for the test of the pudding is in the eating. At the heart of our message are liberation, love and development. We need show that our concept of truth is even pragmatic and a call to action We must be active, for at the heart of knowledge is liberation and development(al) knowledge. We must be creative in order to change our situation.

\section{Towards an African Community}

The choice of the word 'community' instead of 'society' is purposeful. A critical look at the definition of society will reveal the kind of tie involved. For Folliet (1962: 10 ), a society is 'A system of relations between person or groups that keep in view a common end considered by them to be their good'.

There is a patterned system of interaction, it tends to suggest the presence of law. The society is made coherent by its political structures, organization and institutions, Messner (1949: 102) states that society is: 'A unity constituted by a group of men bound together by their needs of mutual supplementation and their aptitude for it'.

In the words of Higgins (1948:360), society is: 'The permanent moral union of two or more people striving for common good by cooperative activity'. 
Fagothey sees it in the same light. But the fact remains that society and community are not the same. Relationship in the community is more humane, human, involving feeling of brotherhood than in the society, more so, 'this relationship is based on love. The members are together on account of feeling, attachment and not necessarily on account of needs.

A pivotal question here is, how do we form this community? We can do this by applying some strategies. These include:

1. Going for knowledge.

2. Searching and seeking for the truth

3. Becoming responsible and creative.

\subsection{Knowledge}

People through the century have assigned the statement, 'knowledge is power' to Bacon. But I know that use of knowledge is power. We need knowledge in order to become powerful. Without knowledge we are like chaffs blow by the wind; in short, dead.

We need knowledge in order to know ourselves, understand ourselves, our environment, our problems, and even to find ways of tackling these problems. World Development Report (1998/99: 16) poignantly expressed:

Knowledge is critical for development, because everything we do depends on knowledge. Simply to live, we must transform the resources we have into the things we need, and that takes knowledge.

If we want to grow, improve, change ourselves, relationships, or environment, there is need for knowledge. We need to seek for knowledge, acquire, absorb and even communicate it for the required or expected change.

First and foremost, we must know that human kind has suffered so much, civilizations destroyed because of lack of knowledge. The Bible in Hosea 4:6 made it too clear that my peoples perish for lack of knowledge.

We must know that the laws of nature are constant, permanent and inviolable; and that nature maintains balance, that what we give to it, it gives us back, no more no less.

We need know and realize that we all are the same, one; in short, that we are inseperable from each other, and as such we must move all out to discover 
man. Man must realize that his greatest asset is man; that man needs man before any other thing, without exchange of service; what will the world amount to"?

We must know that service is a lesson of great worth. Service is at the root of every promising community, for it springs from trust, love and friendship. Lao Russell et al (1981:45) write: The great lesson to learn of life is the need of giving out from the abundance of one's self in order to be ever abundant within one's self.

Nature does not know bargain. It believes in exchange, and sticks to balance. It is ever balanced. Little wonder, Aristotle said that nature does not allow room for a vacuum. Everything in the world is a gap- filler. There is no gap in nature Do you know that to withhold your giving or even giving of self is a way of depriving yourself of fulfillment and development? When you shut off the fountain of the self, you at the same time and in the same degree stagnate and cause to dry the living waters of the self Do you know the value of the statement, it is better to give than to receive? He who gives more multiplies himself, and increases his capacity to give. Think of Jesus,

He gave self, all, and he drew all men to himself. We must know that we are not enemies rather friends and lovers. Man need not compete with fellow men, he should cooperate. Only cooperation will enrich us. Do you know that an unbalanced contract is one of the root causes of fear and hatred in human society? Unbalanced contracts will not bind; they will rather breed discontent and hurt.

Knowledge that unity is our unlearned lesson, need to be disseminated properly in order to root out fear and hatred.

Knowledge of what we have, what distinguishes the African from the rest will help in bringing about this unity faster. Our ontology breeds communalism. Communalism is an extension of our understanding of family which spans from creator - God, spirits, ancestors, living, the dead and not yet born. In this understanding is brotherhood of man.

Nze (1994:30) advocated that:

Social solidarity, compound and corporate existence, collective security, unselfish commitment and humanism, individual and communal freedom which are the true habiliment of communalism become then a natural legacy which ought to be lived, developed, and preserved as a life treasure.

Communalism can aid in ensuring that the hoped for contact between Africans at home and in diaspora be not a false one, so as not to generate a false unity. 
There is every likelihood that proper knowledge of ourselves, our environment and status in the world will make communalism breed patriotism This could be reflected in our taking up the task to ensure that every African man or group knows justice in the world and not allow or consent to any African being treated as an object.

Knowledge will help us read creatively into policies and laws, and see the hidden agenda in these, and as such prevent our people being made 'hewers of wood and drawers of water'. By so doing, we can create the situation for their being treated as subjects with rights.

\subsection{Searching and Seeking for the Truth}

Man by nature desires to know. In short, he craves to know; he is a searcher in different spheres of life. He is equally engaged in the search for truth.

The more we know, the more we are disposed to search for truth. The quest for knowledge and the truth cannot be quenched. Jesus is the light of the world, God-man, the ';Alpha;' and 'Omega', but Christians have continued through ages in search for a better and more vital understanding of this way, truth and life difficult, it shows that we have limitations, even too in our personal move and search, this will tend to make us more humble and disposed all the more to be in the frame of mind to accept the other with all his limitations., Do you know that the other is important for your own truth?

We cannot understand that save we have learnt to listen to the other, this necessitates acceptance of the other. Authentic dialogue is required. Our commitment to truth means acceptance of love and commitment to love.

In listening, we need to listen to the speakers and not merely to the words of the speakers. People have life; words are not alive though they can express meaning and life.

Haring (1979: 18) states: 'We shall never listen just towards just to words for people give the meaning to words. The same word can have opposite meanings for different people or in different circumstances'.

Africans must strive to understand what the other says but equally what the other is, for being is prior to acting and having. It is by really understanding truth that genuine dialogue and involvement can take root. Haring (1979: 19) expressing the thoughts of Pope Paul IV in Ecclesiam Suam states: 
We cannot speak truly of dialogue if one person or group claims possession of the truth and the right to dictate to others. Dialogue presupposes the readiness on both sides to acknowledge their limitedness and to search for more light.

\subsection{Responsibility and Creativity}

To talk of responsibility is to have presupposed freedom both 'freedom from' and 'freedom to'. Responsibility is within the sphere of self-determination. It entails living a conscious life.

Some questions face us now, what ought we to do? What ought we to be? What kind of persons does our project want us to be? Our project expects us to be responsible and creative persons.

If we aspire to live with creative freedom and in fidelity to our project, then, we must understand ourselves and the other. New relationships resulting from inner transformation of our personalities more than new ideas have the potency to change people. We must be involved in relationship with the other(s) if we must know selfhood.

We can become really creative if we come to the full recognition of our identity and wholeness by allowing our entire being to become a trustful, grateful, sincere and loving response to the call to become African, and aid in establishing our project. To become creative, we must be whole, and make our words our bond and our life.

We must work towards an emergent synthesis of our mind, spirit and heart values if actually our clarion call for contact between Africans at home and in diaspora must yield rich fruit. Let us put in our emotions, values and life and see it as a foundational and fundamental decision, and an African community will emerge sooner than thought.

\section{Conclusion}

Having come this far, one need not over labour himself to decipher that the rout to authentic African freedom is dialogue, this can not generate the desired result except if it is matched with involvement.

We must make up our minds, take the risks involved for living itself is even a risk, and participate in every possible way in order to turnaround the present 
state of affair. To act as we have posited and live as we have postulated is to live the African way, communalistic way of life, that is living in communion with others as a being-in-the world of men and a being-with-others. Dialogue and involvement remain the master keys for harmonious contact between Africans at home and in Diaspora.

\begin{abstract}
A scepter of revolution once on the sky has now engulfed human race. It is a revolution against love, truth, peace, happiness, in short everything that is good and beautiful. There is disunity everywhere. We all sit on the keg of gunpowder. The leaders of men think, though wrongly that diplomacy will do.

If the pace and form of human relation is not properly handled, the human race will end in quagmire. We have to base human relations on natures' principles in order to ensure balance; remember nature abhors a vacuum.

Africa is the cradle of humankind, civilization as such it is the onus of African sons and daughters everywhere to ensure that mankind survives. We lost grip of the sciences which led to the Seven Wonders of the World; but we can still reacquire these. Most importantly, values build men and civilization., it is the position of this paper to argue that the use of dialogue in relating with the other will do well to ensure a stable company and relationship, as it rhymes with the position of personalist philosophers, and some existentialists like Martin Buber, Gabriel Marcel, Heidegger, etc for dialogue will eventually lead to cooperation to 'active' involvement. The principles of dialogue, cooperation and involvement or activity will help in ensuring that knowledge and information are acquired, harnessed and used in a highly efficient way to free Africans from the clog of powerlessness in the comity of nations.
\end{abstract}

Key words: dialogue, responsibility, freedom, cooperation

\title{
Bibliography
}

Boethius (2014) Contra Eutychen et Nestorium (The Perfect Library).

Cesaire, A (1972) Discourse on Colonialism trans Joan Pink am N. Y.: Monthly Review Press.

Chukwulozie, V.C. (1979) 'The philosophy of Dialogue' in Chukwulozie (ed) Nigerian Dialogue U.N.N.: Nigerian Secretariat for Non-Christians.

Edwards, P. (1968) The Encrclopedia of Philosophv N. Y.: Macmillian Pub. Co. \& the Free Press. Vol. 5 \& 6 .

Folliet, 1. (1963) Man in His Environment N.Y.: Hawthorn Books Pub.

Freidman, M. (1964) The Worlds of Existentialism N. Y.: Random House.

Haring, B. (1968) The Christian Existentialism N. Y.: University Press.

Haring, B. (1979) Free and Faithful in Christ London: St. Paul's Pub., Vo1.2.

Haring, B. (1981) Free and Faithful in Christ London: S1. Paul's Pub., vol.3. 
Higgins, T.1. (1948, 1949) Man as Man Millwaukee: The Bruce Publishing Co.

Hodek, B. (1978) The Complete Works of Shakespeare Toronto: Hamlyn pub. Co. Ltd.

Ifemeje, C. (1983) Personalism B.A. dissertation in philosophy, Bigard Ikot-Ekpene, Unpublished.

Jaspers, K. (1970) Philosophy vo1.2 Chicago. University of Chicago Press

Mbiti, 1.S. (1969) African Religions and Philosophy London: Heinemann

Messner, J (1949) Social Ethics London: B. Herder Books Co., St. Louis

Nze, C.B. (1994) Patriotism: A Cultural Emanation Onitsha: Veritas Printing \& Publishing Co. Ltd.

Ogugua, P.I. (2001) "Dialogue and nation-Building" in Nigeria Journal of Curriculum and Instruction ed. By Okam, C.c. Vol. 10, No.4

Ogugua, P.I. (2004) "The African Personality" Unpublished.

Onyewuenyi, I.O. (1982) A Philosophical Reeappraisal of African Belief in Reincarnation" in International Philosophical Quarterly. Vol. xx III, No.3 Issue No. 87. N. Y.: Fordham University.

Plattel, M.G. (1965) Social Philosophy (Duquesne Studies) Louvain: Dugquesne University PressRussell, B. (1954) Human Society in Ethics and Politics London: George, Allen \& Unwin Ltd.

Russell Lao \& Walter (1981) Scientific Answer to Human Relations Virginia: The University of Science \& Philosophy.

Sahakian, W.S. (1965) Realms of Philosophy of Sahakian, M.L. Massachusetts: Schenkman Pub. Co.

Schar, H. (1970) Was $1^{\text {st }}$ Wahrheit? Eine Theologisch - Psvchologische Untersuchung Zurich.

Soyinka, W. (1972) The Man Died (Prison Wotes ofWole Soyinka) England: Penguin Books.

Stumpf, S.B. (1971) Philosophy: History and Problems N.Y.: McGraw-Hill Book, Co.

Tempels, P. (1959) Bantu Philosophy Paris: Presence Africaine.

World Development Report: Knowledge For Development Published for the World Bank, Oxford University Press.

Ogugua, Paul I. - Department Of Philosophy, Nnamdi Azikwe University, Awka, Anambra State, Nigeria 